\title{
Classes of secondary metabolites identified in three legume species
}

\section{Delci de Deus Nepomuceno ${ }^{1}$, João Carlos de Carvalho Almeida ${ }^{1}$, Mário Geraldo de Carvalho², Renata Duarte Fernandes ${ }^{2}$, Francisco Eduardo Aragão Catunda Júnior ${ }^{2}$}

\footnotetext{
${ }^{1}$ Departamento de Nutrição Animal e Pastagens, Instituto de Zootecnia, Universidade Federal Rural do Rio de Janeiro, Seropédica, RJ, Brasil.

${ }^{2}$ Departamento de Química, Instituto de Ciências Exatas, Universidade Federal Rural do Rio de Janeiro, Seropédica, RJ, Brasil.
}

ABSTRACT - The objective of this study was to identify secondary metabolite classes of tropical kudzu, perennial soybean and archer legumes through identification by phytochemical screening and confirmation by infrared (IR), ${ }^{1} \mathrm{H}$ and carbon-13 NMR spectroscopy of fractions obtained by organic solvents partition of crude extracts. These analyses allowed for proposing the presence of the following metabolite classes: reducing sugars, saccharides, saponins, cardiac glucosides, terpenes, coumarins, tannins, alkaloids and flavonoids. The tannins, saponins, alkaloids, organic acids and flavonoids had special consideration because they are toxic compounds and can affect the animal metabolism.

Key Words: anti-nutritional factor, anti-qualitative factor, archer, perennial soybean, phytochemical screening

\section{Introduction}

In Brazil, livestock herds are essentially fed pastures because this is the most practical and economical way to feed cattle in this country. Therefore, the quantitative and qualitative improvement of pastures leads to increase in livestock productivity, directly impacting the competitive potential of the country (Silva \& Saliba, 2007).

The use of forage legumes, either in combination with grasses or as a monocrop, is one mechanism for achieving these improvements (Carvalho \& Pires, 2008). Some of the benefits provided by legumes are increase in biological nitrogen fixation, improvement of the diet and an increase in forage intake compared with grass pastures exclusively (Carvalho \& Pires, 2008).

The acceptability of legumes is directly related to the presence of secondary metabolites, which are non-fibrous natural substances that are also produced by plants under stressed conditions and that act as anti-nutritional factors (Gontzea \& Sutzescu, 1968; Gobbo-Neto \& Lopes, 2007). Thus, they cause collateral effects on animal nutrition, interfering with nutrient intake, digestion, absorption and utilization (Allen \& Segarra, 2001).

The tropical kudzu, perennial soybean and archer legumes have demonstrated a remarkable production of dry matter (DM) and crude protein. Pádua et al. (2006) reported 6.03, 4.6 and $6.82 \mathrm{t} \mathrm{DM} \mathrm{ha}^{-1}$, from a single harvesting, and $15.42,16.46$ and $15.15 \%$ of crude protein content in the dry material of archer, perennial soybean and tropical kudzu, respectively. Although chemical analysis indicates good digestibility of forage legumes, especially when only the lignin content is considered, these legumes may not be acceptable for cattle feedstock because their chemical and physical structures impair their consumption, palatability and digestibility, which all compromise their nutritional value (Jerba et al., 2004).

The objective of this study was to identify the main classes of secondary metabolites from archer, perennial soybean and tropical kudzu legumes using three phytochemical screening supported by the techniques: hydrogen nuclear magnetic resonance ( ${ }^{1} \mathrm{H}$ NMR), carbon nuclear magnetic resonance $\left({ }^{13} \mathrm{C} \mathrm{NMR}\right)$ and infrared spectroscopy (IR).

\section{Material and Methods}

Experiments were carried out at the Forage Crops and Pastures Section at the Natural Product Chemistry laboratory of Universidade Federal Rural do Rio de Janeiro (UFRRJ), in Seropédica city, RJ/Brazil. Infrared spectroscopy spectra were recorded on a Nicolet-model 6700 IRFT spectrometer and ${ }^{1} \mathrm{H}$ NMR spectra $(400 \mathrm{MHz})$ and ${ }^{13} \mathrm{C}$ NMR spectra $(100 \mathrm{MHz})$ were recorded on Bruker Advance-II spectrometer.

The seeds of the legumes were sown in individual beds and were fertilized with $250 \mathrm{~kg}$ and $100 \mathrm{~kg} \mathrm{ha}^{-1}$ phosphate $\left(\mathrm{P}_{2} \mathrm{O}_{5}\right)$ and potassium chloride $(\mathrm{KCl})$, respectively, in January 2006. A uniform cutting and soil fertilization with $100 \mathrm{~kg} \mathrm{ha}^{-1}$ of $\mathrm{P}_{2} \mathrm{O}_{5}$ and $\mathrm{KCl}$ were performed according to Van Raij et al. (1996). 
The shoots of tropical kudzu (Pueraria phaseoloides), perennial soybean (Neonotonia wigttii) and archer (Macrotiloma axillare) were harvested in September 2007 and were then dehydrated in the shade. Due to the high moisture content of archer, this legume was dried in an oven at $55^{\circ} \mathrm{C}$ for $16 \mathrm{~h}$. All dried samples were subsequently ground in a Wiley mill (model Tecnal TE 680, Piracicaba, SP, Brazil) with a $1 \mathrm{~mm}$ mesh screen and taken to the laboratory for phytochemical analyses.

To obtain the crude extract of each legume, the dried and milled samples were extracted by maceration at room temperature with methanol, and the solvent was removed by distillation under vacuum with rotatory evaporator.

As the direct chromatographic analysis of crude extract is extremely difficult due to the complexity of the compounds, especially due to the presence of resins and other polymers, polar solvents are used to fractionate the extract. The use of a filtration column or another appropriate environment could easily enable its partitioning in less complex mixtures. This method uses successive washings with solvents of different polarities, which remove some groups of substances with similar properties from the mixture (Matos, 1988).

To obtain the fractions, the crude extract of each legume was suspended in a separator funnel using methanol:water $(8: 2, \mathrm{v} / \mathrm{v})$, and then, sample extracts were partitioned with hexane and ethyl acetate. The solvents of each fraction, hexane, ethyl acetate and hydromethanol, were removed using rotatory evaporator to obtain a residue whose yields were expressed as percentages (Table 1).

The extracts and partitions from each legume were subjected to phytochemical screening to identify the classes of secondary metabolites, according to methodology of Barbosa Filho (2001). Physical methods of organic analysis $\left({ }^{1} \mathrm{H}\right.$ and ${ }^{13} \mathrm{C}$ NMR and IR) were used to support the results obtained through chemical methods.

Samples of crude extracts and partitions were diluted in adequate solvent such as $\mathrm{CDCl}_{3}, \mathrm{D}_{3} \mathrm{COD}$ or DMSO-D, according to the polarity, for ${ }^{1} \mathrm{H}$ and ${ }^{13} \mathrm{C}$ NMR analyses

Table 1 - Yield of extracts and partitions of the tropical kudzu, perennial soybean and archer forage legumes

\begin{tabular}{lccc}
\hline & \multicolumn{3}{c}{ Legumes } \\
\cline { 2 - 4 } Extract/partition & $\begin{array}{c}\text { Tropical } \\
\text { kudzu }\end{array}$ & Archer & $\begin{array}{c}\text { Perennial } \\
\text { soybean }\end{array}$ \\
\hline Original dry matter (kg) & 2.296 & 2.206 & 1.758 \\
Methanolic extract (\%) & 5.0 & 10.3 & 7.5 \\
Hexanic partition (\%) & 1.7 & 1.2 & 2.2 \\
Ethyl acetate partition (\%) & 1.2 & 4.0 & 0.8 \\
Hydromethanol partition (\%) & 1.0 & 2.1 & 1.4 \\
\hline
\end{tabular}

(approximately $10 \mathrm{mg}$ and $100 \mathrm{mg}$ per sample, respectively). The solutions were placed into glass tubes $(5 \times 15 \mathrm{~mm})$.

To obtain IR spectra, solid samples (approximately $2 \mathrm{mg}$ ) were mixed in potassium bromide $(\mathrm{KBr})$ and then ground and pressurized to obtain transparent pressed-disc, and the gum samples were then analyzed on a $\mathrm{NaCl}$ film, with $600-4000 \mathrm{~cm}^{-1}$.

The results of the screening were presented by crosssystem methodology: three crosses $(+++)$ represent a large presence of the compound, two crosses $(++)$ represent a medium presence, a single cross $(+)$ represents a small presence or trace and a hyphen (-) means absence of the compound or an inconclusive result. The color, form and precipitate of each sample were evaluated by two researchers to define the presence or absence of the metabolites, and the intensity was obtained by comparisons among the partition/extracts of the studied legumes. The result from each metabolite class was confirmed by ${ }^{1} \mathrm{H}$ and ${ }^{13} \mathrm{C} \mathrm{NMR}$ and/or IR analyses.

Each class of metabolites has characteristic signals, including specific chemical shifts in ${ }^{1} \mathrm{H}$ and ${ }^{13} \mathrm{C}$ spectra as well as the frequency of functional organic groups in IR spectra, which can be used to indicate the presence of these metabolite classes.

These analyses were performed on each class of compounds by observing characteristic absorptions in the spectra, and the number of crosses was recorded based on the abundance of signals compatible with the parts of compounds belonging to each metabolite classes. For example, the presence of saponin is indentified by the strong absorptions of sugars by $3500-3100 \mathrm{~cm}^{-1}\left(v_{\mathrm{OH}}\right)$, $1100-1200 \mathrm{~cm}^{-1}\left(v_{\mathrm{C}-\mathrm{O}}\right)$ and of terpene moiety by $2900-2850$, $1460,1380 \mathrm{~cm}^{-1}\left(v_{\mathrm{CH}}\right.$ and $\delta_{\mathrm{CH}}$ of $\mathrm{CH}_{2}$ and $\left.\mathrm{CH}_{3}\right)$. This class of metabolites is identified in the ${ }^{1} \mathrm{H}$ and ${ }^{13} \mathrm{C}$ NMR spectra by the signals of sugars at $\delta_{\mathrm{H}}: 2.5-5.5 \mathrm{ppm}\left(\mathrm{CH}_{2}\right.$ and $\left.\mathrm{CH}\right)$ including doublet of the anomeric proton and $\delta_{\mathrm{C}} 61-88$ and $99-105$ of $\left(\mathrm{O}-\mathrm{CH}_{2}\right.$ and $\mathrm{O}-\mathrm{CH}$, and $\left.\mathrm{O}-\mathrm{CH}-\mathrm{O}\right)$, respectively. The terpene moiety can be identified by signal between $\delta_{\mathrm{H}}: 0.8-2.4$ and $\delta_{\mathrm{C}} 14-60 \mathrm{ppm}$, in the ${ }^{1} \mathrm{H}$ and ${ }^{13} \mathrm{C}$ NMR espectra, respectively. The fractions or extracts that have carbohydrate as principal components yield spectra with those signals of sugars only. The tannins can be identified by absorptions of phenols and aromatic systems [3300, 1200, $\left.1600-1450 \mathrm{~cm}^{-1}\left(v_{\mathrm{OH}}, v_{\mathrm{C}-\Theta}, v_{\mathrm{C}=\mathrm{c}}\right)\right]$. The NMR spectra show signals of nucleus in the aromatic systems such as protons at $\delta_{\mathrm{H}}: 7.6-6.3$ and carbon-13 at $\delta_{\mathrm{C}} 166-143$ of oxygenate quaternary carbons $(\mathrm{O}-\underline{\mathrm{C}}=\mathrm{C}), 130-110$ of methinic carbons $(=\underline{\mathrm{C}}-\mathrm{H})$. The organic acids are identified by typical signals of carbonyl group besides signals of aliphatic chain [1700, $2960-2850,1460,1200-1300$ and 720 of $v_{\mathrm{C}=\mathrm{O}}, v_{\mathrm{C}-\mathrm{H}^{2}} \delta_{\mathrm{C}-\mathrm{H}}$, 
$v_{\mathrm{C}-\mathrm{O}}$ and $\delta_{\mathrm{C}-\mathrm{H}}\left(\mathrm{CH}_{2}\right)$, respectively)] besides others signals. In the ${ }^{1} \mathrm{H}$ and ${ }^{13} \mathrm{C}$ NMR spectra it is identified by signals at $\delta_{\mathrm{H}}$ near: $1.0\left(\mathrm{CH}_{3}\right), 1.24\left(\mathrm{CH}_{2}\right), 1.80\left(\mathrm{CH}_{2}\right)$ and $2.2\left(\mathrm{CH}_{2}\right.$, triplet), and $\delta_{\mathrm{C}}$ near: $14.0\left(\mathrm{CH}_{3}\right), 19.0-19.7,22.0,25.0$, 30.0, $34.0\left(\mathrm{CH}_{2}\right)$ and 180-173 $\left(-\mathrm{CO}_{2}\right)$. Additional signals can indicate the presence of ester $\left(\delta_{\mathrm{H}}: 3-5-4.8 ; \delta_{\mathrm{C}}: 60-77\right.$ of $\mathrm{CH}$ or $\mathrm{CH}_{2}$ ) and or/and double bond with signals at $\delta_{\mathrm{H}}$ near 6.1-6.5 and $\delta_{\mathrm{CH}} 128-132 \mathrm{ppm}$. Certain classes of metabolites are identified by chemical screening such as alkaloids, catechins, depsides, depsidones, lactones and other ones were not confirmed by spectra because they do not provide reliable results due to difficult interpretation or masking effects.

\section{Results and Discussion}

These analyses of the presence of secondary metabolites in methanolic extracts and hexanic, ethyl acetate and hydromethanol partitions of each legume (Tables 2, 3 and 4) confirm the classes of secondary metabolites present in the three species of legumes studied here.

According to Givens et al. (2000), the secondary metabolites are classified into two groups:

1) Toxic compounds that are present at low concentrations (usually less than $20 \mathrm{~g} \mathrm{~kg}^{-1}$ of dry matter) and that have negative physiological effects when absorbed by animals, such as neurological problems, reproductive failure, goiter, gangrene, other illnesses and fatalities. They are represented by alkaloids, cyanogenic glycosides, toxic amino acids, saponins, isoflavones and many other compounds.

2) Non-toxic compounds present in high concentrations (higher than $20 \mathrm{~g} \mathrm{~kg}^{-1}$ ), which have effects associated with decreased digestibility, palatability and animal feeding behavior. This class includes lignin, tannin, cutin, biogenic silica and volatile terpenoids.

Organic acids, reducing sugars, depsides, depsidones, coumarin by-products, steroids, triterpenoids, cardiac glycosides, saponins, saccharides, flavonoids and tannins were found in the studied forage legumes. It can be observed that archer differs from tropical kudzu and perennial soybean in its absence of alkaloids (Table 5).

Secondary metabolites act as anti-nutritional and/or anti-qualitative factors, causing negative effects, losses and expenses, whose magnitude depends on the value of the animal or the number of affected animals (Allen \& Segarra, 2001).

Tannins are considered to be the main negative factor in legumes regardless of the acceptability of the legumes by the animal (Reed, 1995; Beelen et al., 2006; Lempp, 2007).

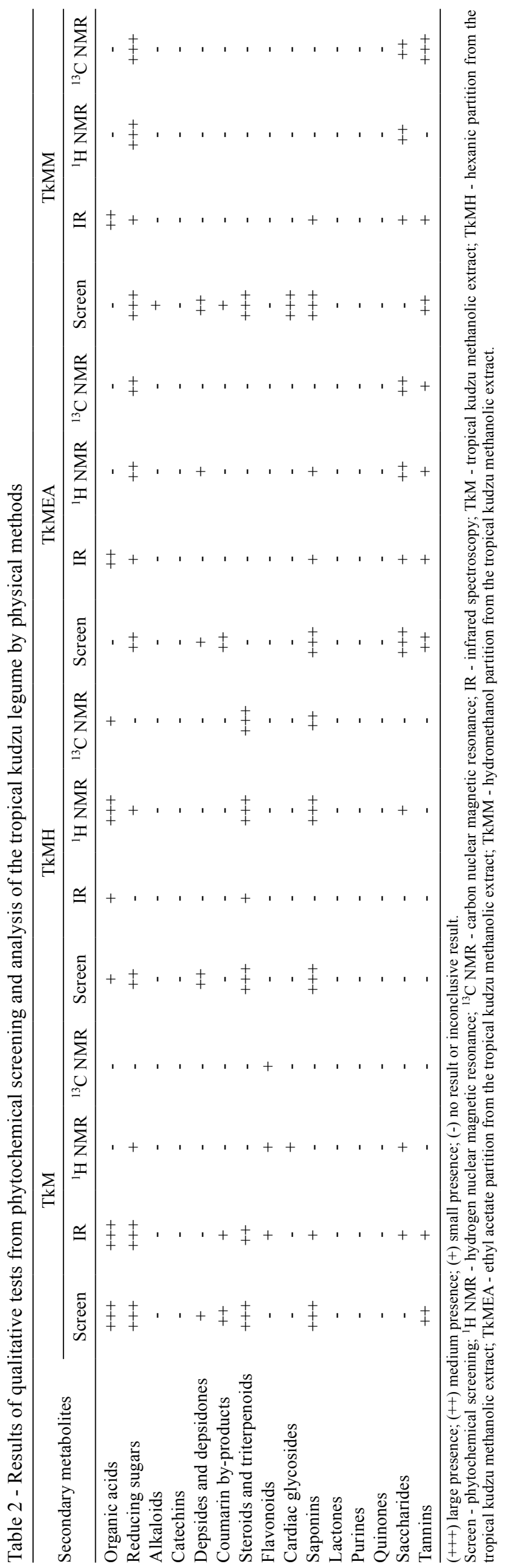

R. Bras. Zootec., v.42, n.10, p.700-705, 2013 

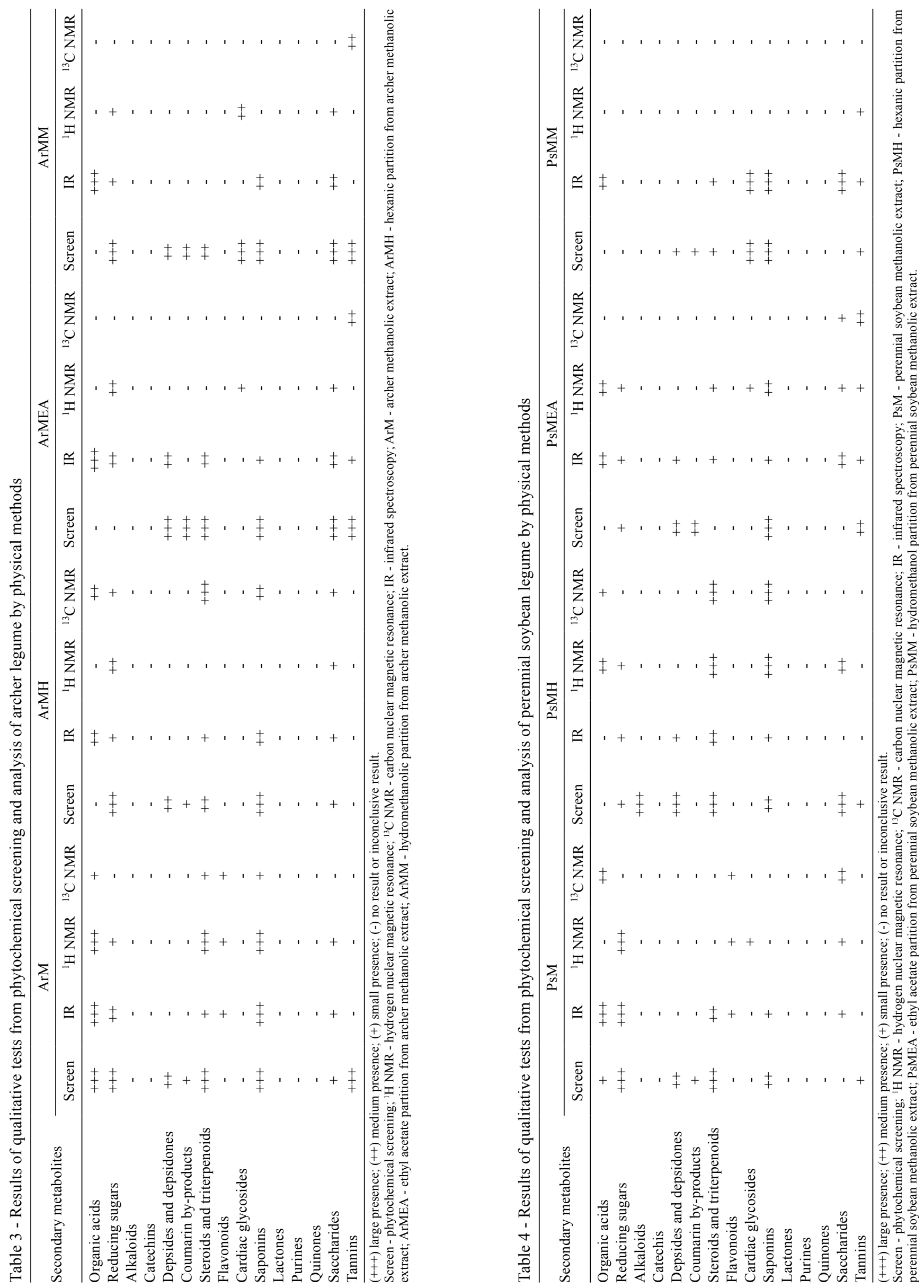

R. Bras. Zootec., v.42, n.10, p.700-705, 2013 
However, the saponins are able to produce stable foams in water, which can cause tympanism, reduce fermentation and cause hepatic photosensitivity. Sustained foams also indicate a bitter flavor, which decreases the acceptability of the legumes and intake by the animals (Ramos et al., 1998).

The depsides and depsidones in legumes are related to selectivity of forages and can negatively influence animal intake due to their bitter flavor (Baraúna et al., 2007), acting in concert with tannins and saponins.

The presence of steroids and triterpenoids in these legumes can be directly associated with the reproductive performance of the flock due their contraceptive effects (Fracaro, 2004). Coumarins have the same role, showing estrogenic and fungicidal activities (Agudelo, 2007).

Organic acids act as triggers for the precipitation of $\mathrm{Ca}$ ions in the blood, causing hypocalcemia syndrome, muscle weakness, nephritis, kidney stones and gastrointestinal irritation in grazing ruminants and horses (Rosa \& Fichtner, 1993). However, the alkaloids can trigger some alterations in food ingestion and chewing, diarrhea, nervous symptoms and sudden death (Sousa \& Irigoyen, 1999).

Legume saccharides, including raffinose, stachiose and verbascose cause negative effects on monogastric animals (e.g., humans and experimental animals) such as flatulence and colic and intestinal ailments (Oliveira et al., 2001a; Oliveira et al., 2001b).

Reducing sugars are problematic mainly for equines fed diets with a high concentrate content, since they eat nonstructural carbohydrates, producing excess lactic acid and gas. High concentrations of lactic acid cause water retention, reduce the lumen $\mathrm{pH}$ to values below 6 and increase the risk

Table 5 - Summary of qualitative tests from phytochemical screening and analysis of the legumes and partitions by physical methods (IR, ${ }^{1} \mathrm{H}$ and ${ }^{13} \mathrm{C}$ NMR)

\begin{tabular}{|c|c|c|c|}
\hline \multirow[b]{2}{*}{ Secondary metabolites } & \multicolumn{3}{|c|}{ Legumes } \\
\hline & $\begin{array}{c}\text { Tropical } \\
\text { kudzu }\end{array}$ & Archer & $\begin{array}{c}\text { Perennial } \\
\text { soybean }\end{array}$ \\
\hline Organic acids & +++ & +++ & ++ \\
\hline Reducing sugars & +++ & ++ & + \\
\hline Alkaloids & + & - & + \\
\hline Catechins & - & - & - \\
\hline Depsides and depsidones & + & ++ & + \\
\hline Coumarin by-products & + & ++ & + \\
\hline Steroids and triterpenoids & ++ & +++ & ++ \\
\hline Flavonoids & + & + & + \\
\hline Cardiac glycosides & + & + & ++ \\
\hline Saponins & +++ & +++ & +++ \\
\hline Lactones & - & - & - \\
\hline Purines & - & - & - \\
\hline Quinones & - & - & - \\
\hline Saccharides & ++ & +++ & ++ \\
\hline Tannins & +++ & +++ & ++ \\
\hline
\end{tabular}
inconclusive result of secondary metabolites. of digestive disorders, which are associated with osmotic diarrhea and colic ailments (Cohen et al., 1999).

The nutritional value is affected by non-nutritional factors, but their analyses have not been previously considered in tests (the complexes of proteins with phenolic compounds have not been evaluated).

However, the hypothesis that there may be beneficial effects from secondary metabolites such as tannins and saponins should not be disregarded (Sliwinski et al., 2002). Both tannins and saponins can be potentially used to mitigate ruminal methane production (Puchala et al., 2005; Min et al., 2006; Jayanegara et al., 2009; Goel \& Makkar, 2012); furthermore, condensed tannins can be used as an alternative medicine to control the gastrointestinal helminths of ruminants (Min \& Hart, 2003; Rojas et al., 2006).

\section{Conclusions}

The presence of secondary metabolites such as tannins and saponins in the tropical kudzu, perennial soybean and archer legumes suggests the possibility of negative effects when they are used as feedstock. Screens for the metabolites catechins, lactones, purines and quinones demonstrated negative or inconclusive results due to difficulty and/or misreading due to the mixture of signals in the spectra. The other classes of secondary metabolites, such as organic acids, reducing sugars, coumarin by-products, depsides and depsidones, alkaloids, steroids, triterpenoids, flavonoids and cardiac glycosides (not including carbohydrates, amino acids, lipids, vitamins and minerals) can cause negative effects when used as feedstock, so these should be better monitored in animal feeding.

\section{Acknowledgments}

The authors thank Coordenação de Aperfeiçoamento de Pessoal de Nível Superior (CAPES) for the followship granted to the first author; Fundação Carlos Chagas Filho de Amparo à Pesquisa do Estado do Rio de Janeiro (FAPERJ) and Conselho Nacional de Desenvolvimento Científico e Tecnológico (CNPq) for the financial support; and the companies Sementes Matsuda and Sementes Selegram for providing the legume seeds.

\section{References}

AGUDELO, J.C.C. Efecto de la utilización de arbóreas y arbustivas forrajeras sobre a dinâmica digestiva em bovinos. Revista Lasallista de Investigación, v.4, p.39-50, 2007.

ALLEN, V.G.; SEGARRA, E. Anti-quality components in forage: Overview, significance, and economic impact. In: 
LAUNCHBAUGH, K. (Ed.) Anti-quality factors in rangeland and pastureland forages. Station Bulletin 73 of the Idaho Forest, Wildlife, and Range Experiment Station, University of Idaho, 2001. p.1-4.

BARAÚNA, R.A.; NEVES, A.N.; ROCHA, J.C.S. et al. Avaliação fitoquímica e farmacológica do extrato aquoso de Eleutherine plicata. In: REUNIÃO ANUAL DA SBPC AMAZÔNIA: DESAFIO NACIONAL, 59., 2007, Belém. Anais... Belém: Universdidade Federal do Pará, 2007. 2p.

BARBOSA FILHO, J.M. Triagem fitoquímica. João Pessoa: Departamento de Ciências Farmacêuticas, Universidade Federal da Paraíba, 2001. 10p. (Apostila Técnica).

BEELEN, P.M.G.; BERCHIELLI, T.T.; BUDDINGTON, R. et al. Efeito dos taninos condensados de forrageiras nativas do semiárido nordestino sobre o crescimento e atividade celulolítica de Ruminococcus flavefaciens FD1. Arquivo Brasileiro de Medicina Veterinária e Zootecnia, v.58, p.910-917, 2006.

CARVALHO, G.G.P.; PIRES, A.J.V. Leguminosas tropicais herbáceas em associação com pastagens. Archivos de Zootecnia, v.57, p.103-113, 2008.

COHEN, N.D.; GIBBS, P.G.; WOODS, A.M. Dietary and other management factors associated with colic in horses. Journal of the American Veterinary Medical Association, v.215, p.53-60, 1999.

FRACARO, S.N. Potencial de toxicidade reprodutiva do extrato de Tillandsia usneoides Linnaeus, 1762 (Barba-de-pau) em coelhos gestantes. 2004. 71f. Dissertação (Mestrado em Ciências Veterinárias) - Universidade Federal do Paraná, Curitiba.

GIVENS, D.I.; OWEN, E.; AXFORD, R.F.E. et al. Forage evaluation in ruminant nutrition. London: Cabi Publishing, 2000. 480p.

GOBBO-NETO, L.; LOPES, N.P. Plantas medicinais: fatores de influência no conteúdo de metabólitos secundários. Química Nova, v.30, p.374-38, 2007.

GOEL, G.; MAKKAR, H.P. Methane mitigation from ruminants using tannins and saponins. Tropical Animal Health and Production, v.44, p.729-739, 2012.

GONTZEA, I.; SUTZESCU, P. Natural antinutritive substances in feedstuffs and forages. 3.ed. New York: S. Karger, 1968. $356 \mathrm{p}$.

JAYANEGARA, A.; TOGTOKHBAYAR, N.; MAKKAR, H.P.S. et al. Tannins determined by various methods as predictors of methane production reduction potential of plants by an in vitro rumen fermentation system. Animal Feed Science and Technology, v.150, p.230-237, 2009.

JERBA, V.F.; MEDEIROS, S.R.; FERNANDES, C.D. Forrageiras: principais fatores de antiqualidade. Campo Grande: Embrapa Gado de Corte, 2004. 38p. (Documentos, 150).

LEMPP, B. Avanços metodológicos da microscopia na avaliação de alimentos. Revista Brasileira de Zootecnia, v.36, p.316-319, 2007.

MATOS, F.J.A. Introdução a fitoquímica experimental. Fortaleza: Edições UFC, 1988. 124p.
MIN, B.R.; HART, S.P. Tannins for suppression of internal parasites. Journal of Animal Science, v.81, p.102-109, 2003.

MIN, B.R.; PINCHAK, W.E.; ANDERSON, R.C. et al. Effects of condensed tannins supplementation level on weight gain and in vitro and in vivo bloat precursors in steers grazing winter wheat. Journal of Animal Science, v.84, p.2546-2554, 2006.

OLIVEIRA, A.C.; CARRARO, F.; REIS, S.M.P.M. et al. A eliminação da água não absorvida durante a maceração do feijão-comum aumentou o ganho de peso em ratos. Revista de Nutrição, v.14, p.153-155, 2001a.

OLIVEIRA, A.C.; QUEIROZ, K.S.; HELBIG, E. et al. O processamento doméstico do feijão-comum ocasionou uma redução nos fatores antinutricionais fitatos e taninos, no teor de amido e em fatores de flatulência rafinose, estaquiose e verbascose. Archivos Latinoamericanos de Nutrición, v.51, p.276-283, 2001 b.

PÁDUA, F.B.; ALMEIDA, J.C.C.; SILVA, T.O. et al. Produção de matéria seca e composição químico-bromatológica do feno de três espécies de leguminosas forrageiras tropicais em dois sistemas de cultivo. Ciencia Rural, v.36, p.1253-1257, 2006.

PUCHALA, R.; MIN, R.B.; GOETSCH, A.L. et al. The effect of a condensed tannin-containing forage on methane emission by goats. Journal of Animal Science, v.83, p.182-186, 2005.

RAMOS, G.; FRUTOS P.; GIRÁLDES, F.J. et al. Los compuestos secundarios de las plantas en la nutrición de los herbívoros. Archivos de Zootecnia, v.47, p.597-620, 1998.

REED, J.D. Nutritional toxicology of tannins and related polyphenols in forage legumes. Journal of Animal Science, v.73, p.1516-1528, 1995.

ROSA, B.; FICHTNER, S.S. Avaliação do conteúdo de acido oxálico capim andropogon (Andropogon gayanus var. bisquamulatos cv. Planaltina) em diferentes idades de corte. Pesquisa Agropecuária Tropical, v.23, p.119-127, 1993.

ROJAS, D.K.; LÓPEZ, J.; TEJADA, I. et al. Impact of condensed tannins from tropical forages on Haemonchus contortus burdens in Mongolian gerbils (meriones unguiculatus) and Pelibuey lambs. Animal Feed Science and Technology, v.128, p.218-228, 2006.

SILVA, J.J.; SALIBA, E.O.S. Pastagens consorciadas: uma alternativa para sistemas extensivos e orgânicos. Veterinária e Zootecnia, v.14, p.8-18, 2007.

SLIWINSKI, B.J.; SOLIVA, C.R.; MACHMÜLLER, A. et al. Efficacy of plant extracts rich in secondary constituents to modify rumen fermentation. Animal Feed Science and Technology, v.101, p.101-114, 2002.

SOUSA, R.S.; IRIGOYEN, L.F. Intoxicação experimental por Phalaris angusta (Gramineae) em bovinos. Pesquisa Veterinária Brasileira, v.19, p.116-122. 1999.

VAN RAIJ, B.; CANTARELA, H.; QUAGGIO, J.A. et al. Recomendações de adubação e de calagem para o Estado de São Paulo. 2.ed. Campinas: Instituto Agronômico e Fundação IAC, 1996. 285p. (Boletim Técnico, 100). 